Людмила Мороз

Сумський державний педагогічний університет імені А. С. Макаренка ORCID ID 0000-0001-6087-1252

Лариса Стахова

Сумський державний педагогічний університет імені А. С. Макаренка ORCID ID 0000-0002-0540-0674

Анатолій Кравченко

Сумський державний педагогічний університет імені А. С. Макаренка ORCID ID 0000-0002-9523-7435

Ірина Кравченко

Сумський державний педагогічний університет імені А. С. Макаренка ORCID ID 0000-0001-9240-5993 Катерина Зелінська-Любченко

Сумський державний педагогічний університет імені А. С. Макаренка ORCID ID 0002-9986-4989

DOI 10.24139/2312-5993/2020.10/167-176

\title{
СУЧАСНІ ПРОБЛЕМИ ТА ПЕРСПЕКТИВИ ПРОФЕСІЙНОЇ ПІДГОТОВКИ МАЙБУТНІХ УЧИТЕЛІВ-ЛОГОПЕДІВ
}

На підставі вивчення науково-методичної, спечіальної літератури, електронних ресурсів та зіставлення різних поглядів щодо проблеми дослідження, авторами конкретизовано основні проблеми й визначено перспективи професійної підготовки майбутніх учителів-логопедів у закладах вищої освіти на сучасному етапі розвитку суспільства. Прогресивними напрямами оптимізації освітнього прочесу авторами визначено: використання актуальних наукових досягнень; урахування вітчизняних традицій та новітніх розробок провідних країн світу; оновлення дидактичного забезпечення та створення ефективних умов для професійного й особистісного саморозвитку майбутнього успішного фахівця-логопеда.

Ключові слова: професійна підготовка, професійна компетентність, майбутній учитель-логопед, студенти-логопеди, заклад вищої освіти.

Постановка проблеми. Сучасний цивілізаційний розвиток нашої держави створює нові вимоги щодо належного забезпечення всіх сфер життєдіяльності населення, зумовлюючи суттєві політичні, економічні, соціальні та освітні перетворення. Бурхливі перетворення сучасного суспільства спричиняють постійне зростання запитів щодо підготовки компетентного фахівця, зокрема в галузі спеціальної освіти. Трансформація вітчизняної освітньої системи, орієнтація на новітні освітні тенденції і світові досягнення викликає зміну поглядів щодо професійної підготовки майбутніх учителів-логопедів. Наразі в суспільстві визначається висока соціальна 
значимість професії логопеда, здатного вирішувати все більш складні фахові завдання та приймати нові професійні виклики. Така ситуація зумовлена не лише постійним збільшенням кількості дітей із порушенням мовленнєвого розвитку різного ґенезу та ускладненням структури мовленнєвих розладів, а й зміною освітніх пріоритетів, упровадженням нових державних освітніх концепцій і стандартів, переходом на новий зміст і структуру освіти дітей із порушенням психофізичного розвитку, зокрема мовлення.

3 огляду на це, в умовах сьогодення закладам вищої освіти належить здійснювати моніторинг та своєчасно реагувати на зміни соціальних запитів, корегуючи стратегію підготовки фахівців відповідно до актуальних потреб та вимог (Дегтяренко, 2015, с. 7). Зокрема, важливим завданням сьогодення $є$ розробка прогресивних напрямів удосконалення професійної підготовки майбутніх учителів-логопедів.

Аналіз актуальних досліджень. Різним питанням професійної підготовки майбутніх учителів присвячені фундаментальні дослідження В. Андрущенка, І. Беха, І. Зязюна, В. Кременя, В. Сластьоніна, Т. Сорочан тощо. Проблеми професійної компетентності майбутніх учителів розглядались у роботах О. Абдуліної, С. Архангельського, В.Береки, . Васильєва, В. Євдокимова, А. Кірсанова та ін. Проблеми професійної компетентності майбутніх учителів-логопедів визначались у дослідженнях О. Жукатинської Т. Корнійченко, О. Кузенко, О. Марченко, Ю. Пінчук, Ю. Ріюцун, Н. Сінопальникової та ін. Проблеми професійної підготовки майбутніх спеціальних педагогів, зокрема і вчителів-логопедів, розглядались у дослідженнях В. Бондаря, Т.Дегтяенко, І. Дмітрієвої, О. Марченко, С. Миронової, Н. Пахомової, В. Синьова, Л. Федорович, С. Федоренко, С. Цимбал-Слатвінської, В. Шевченка, М. Шеремет та ін.

Означені дослідження розкривають значущість проблеми, наголошують на необхідності постійного критичного аналізу та пошуку шляхів оптимізації підготовки фахівців означеного профілю в закладах вищої освіти.

Таким чином, мета статті полягає у визначенні основних проблем та окресленні прогресивних напрямів професійної підготовки майбутніх учителівлогопедів у закладах вищої освіти на сучасному етапі розвитку суспільства.

Методи дослідження: аналіз, систематизація й узагальнення даних науково-методичної, спеціальної літератури та електронних ресурсів; аналіз виступів провідних науковців галузі спеціальної освіти, обговорення актуальних питань та викликів на науково-практичних заходах різного рівня і зіставлення різних поглядів щодо проблеми дослідження. 
Методологічними засадами дослідження стали положення щодо діалектичного підходу до пізнання явищ оточуючої дійсності; єдності та взаємообумовленості теорії і практики освіти; ролі діяльності й активності в розвитку особистості.

Виклад основного матеріалу. Сьогодні перед українською системою вищої педагогічної освіти постають нові виклики. Провідні науковці наголошують, що підготовка кваліфікованих спеціалістів для роботи в нових умовах спеціальної освітньої системи потребує модернізації (Синьов, 2015, с. 393). Існує необхідність критичного аналізу й переосмислення попереднього досвіду підготовки фахівців та пошуку нових підходів до професійної підготовки студентів у закладах вищої освіти (Шеремет, 2020, с. 6).

Наукові розвідки переконливо свідчать, що існуюча система професійної підготовки майбутніх учителів-логопедів у сучасних умовах виправдовує себе лише частково. Наразі існує потреба підготовки нової генерації вчителів-логопедів - кваліфікованих фахівців, які не лише володіють необхідними знаннями, уміннями та навичками, але і здатних до особистісного розвитку, творчої самореалізації, постійного професійного самовдосконалення, відкритих до взаємодії, тобто фахівців із активною професійною позицією, здатних ефективно здійснювати специфічну професійну діяльність у сучасних умовах.

3 огляду на зазначене вище, професійну підготовку майбутніх учителівлогопедів необхідно розглядати як складний, динамічний, багатокомпонентний та багаторівневий процес. Цей цілеспрямований та керований процес повинен забезпечувати формування професійної компетентності й особистісних якостей майбутнього вчителя-логопеда для ефективного здійснення ним фахової діяльності (Сінопальникова, 2014, с. 179).

Сучасна система професійної підготовки фахівців спеціальної освіти, зокрема майбутніх учителів-логопедів, перебуває в стані реформування та потребує розроблення нових освітніх стратегій з урахуванням сучасних світових тенденцій підготовки фахівців у галузі спеціальної освіти (зокрема логопедії). Такі орієнтири, на наше переконання, дадуть змогу підвищувати конкурентоздатність закладів освіти та готувати фахівців належного, відповідного світовим стандартам рівня, здатних забезпечувати не лише потреби внутрішньодержавного ринку праці, а й скласти належну конкуренцію випускникам провідних європейських вищих закладів освіти. У цьому контексті пріоритетним $€$ посилення співробітництва з провідними, передусім, європейськими закладами вищої освіти (зокрема слов'янськими країнами, ураховуючи мовну та мовленнєву специфіку професійної діяльності 
логопеда; близькість Україні щодо історичного, економічного, культурного розвитку; країнами, які є членами Європейського Союзу) в напрямі наукового, практичного, організаційного, управлінського тощо співробітництва. Збільшення участі провідних науковців у міжнародних проєктах, конференціях і семінарах з обміну досвідом, стажування науковопедагогічних працівників у провідних закладах європейських країн, участь студентів у міжнародних стажуваннях та різноманітних студентських заходах (форумах, симпозіумах, фестивалях, майстер-класах тощо).

Як наголошує М. Шеремет (Шеремет, 2020, с. 7), посиленої уваги в цьому контексті потребує проблема активізації працевлаштування випускників із України в європейському чи міжнародному просторі, яка повинна вирішуватись як на загальнодержавному, так і місцевому, університетському рівнях.

Принагідно зазначимо, що в усьому світі показник працевлаштування випускників закладів вищої освіти визнається головним індикатором якості та економічної ефективності національних освітніх систем. Незважаючи на реформування національної системи вищої освіти, їі інтеграцію в освітній та науковий європейський простір, в Україні й досі відсутня національна система регулярного моніторингу працевлаштування випускників не лише за кордоном, але й у межах нашої країни (Гринькевич, 2019, с. 129). Наразі актуальним викликом для Україні $€$ необхідність створення державної електронної бази даних працевлаштування випускників закладів вищої, зокрема спеціальної освіти, з використання прогресивного міжнародного досвіду.

Разом із тим, важливим завданням реформування вищої спеціальної освіти України повинен залишатись орієнтир на збереження культурних надбань національної освітньої системи, що передбачає збереження традиційних і створення сучасних національних особливостей. На наш погляд, професійна підготовка сучасних учителів-логопедів повинна втілювати найкращі вітчизняні традиції й надбання, ураховувати існуючі особливості системи освіти дітей із порушенням психофізичного розвитку, а також збагачувати її інноваційними закордонними розробками, грамотно та гармонійно впроваджувати новітні досягнення, творчо адаптувати актуальний світовий досвід із урахуванням об'єктивних реалій сьогодення.

В Україні є ким і чим пишатися. Закордонними спеціалістами визнаються й високо цінуються методологічні та теоретичні напрацювання провідних вітчизняних науковців (Синьов, 2015, с. ). Так, далеко за межами України відомі наукові школи В. Бондаря, Т. Вісковатової, В. Засенка, Т. Сак, В. Синьова, М.Шеремет та ін. Теоретико-практичні напрацювання 
представників цих наукових шкіл складають основу вітчизняної системи спеціальної та інклюзивної освіти, довели свою ефективність та актуальність і викликають значний інтерес у зарубіжних колег.

Важливим чинником оптимізації професійної підготовки майбутніх учителів-логопедів у закладах вищої освіти $\epsilon$ використання актуальних досягнень у галузі педагогіки, психології, медицини та інших суміжних галузях науки. Існує необхідність постійного підвищення рівня теоретичної та практичної підготовки, проведення досліджень із використанням сучасного обладнання й технологій, опанування новітніми методами дослідження, набуття досвіду проведення науково-дослідної роботи та впровадження ії результатів у практичну діяльність.

Майбутні вчителі-логопеди потребують ґрунтовної фундаментальної підготовки з медико-біологічних та психолого-педагогічних, спеціальних дидактичних дисциплін із метою формування належного рівня діагностичної, консультативної, корекційно-розвиткової та навчально-виховної компетентностей (Пахомова, 2017, с. 375). У першу чергу така підготовка повинна відбуватися на засадах системності та інтеграції медико-психологічних і педагогічних складових (Пахомова, 2013) та практичної орієнтованості на професійну діяльність учителя-логопеда. Ефективність і результативність системності педагогічної, психологічної та медичної підготовки вчителівлогопедів повинна оцінюватися з методологічних позицій, які мають бути покладені в основу подальшого теоретичного й експериментального дослідження цієї проблеми в закладах вищої освіти (Пахомова, с. 192).

Крім того, фундаментальна підготовка має бути не лише актуальною на момент навчання, але й випереджальною. У бурхливому інформаційному суспільстві дуже швидко інформація стає не актуальною, застарілою. А, отже, процес професійної підготовки майбутніх учителів-логопедів потребує прогностичного підходу на основі моніторингу основних новітніх розробок у різних, суміжних галузях науки і практики та постійного оновлення на цій основі освітньо-професійних програм із метою підготовки актуального, на момент закінчення закладу вищої освіти, фахівця.

Переорієнтація вітчизняної системи на передові освітні досягнення та стандарти освіти зумовлює зміну поглядів щодо підготовки майбутніх учителів-логопедів шляхом упровадження компетентнісного підходу як сучасної парадигми розвитку освіти. Реалізація компетентністного підходу вимагає від закладів вищої освіти такої організації освітнього процесу, яка 6 забезпечувала здобувача не лише знаннями, уміннями та навичками, а й розвивала професійно значущі особистісні якості, формувала здатність 
аналізувати та вирішувати проблемні ситуації, обирати оптимальні варіанти їх вирішення (Мороз, 2020, с. 206).

Компетентністний підхід також виступає як шлях реальної співпраці закладів вищої освіти та роботодавців, за якої останні виступають не лише в ролі «споживачів», але й активних «замовників» освітніх послуг, висловлюючи свої погляди щодо підготовки компетентного фахівця. Така взаємодія спрямована на практико орієнтовану підготовку сучасного фахівця, покликана об'єднувати науково-теоретичну підготовку 3 практичною діяльністю, орієнтувати освітній процес на професійні реалії сьогодення (Моро3, 2020, с. 206).

Наразі суспільству потрібні не лише високоосвічені, добре теоретично й практично підготовлені, а й компетентні вчителі-логопеди, здатні швидко адаптуватися до нових умов праці, брати на себе відповідальність за свої професійні рішення та дії, готові швидко переучуватися, навчатися та самовдосконалюватися протягом усього життя. Такі виклики потребують своєчасного реагування з боку закладів вищої освіти шляхом ініціювання постійного перегляду та оновлення стандартів вищої освіти за спеціальністю 016 Спеціальна освіта.

На сучасному етапі розвитку вищої спеціальної освіти, зокрема логопедичної, визначається необхідність оновлення змісту, форм та методів підготовки майбутніх учителів-логопедів, їх приведення у відповідність до вимог та потреб сучасності. Упровадження інноваційного, інтерактивного, технологічного дидактичного забезпечення у процес професійної підготовки повинно сприяти підготовці висококваліфікованих, компетентних фахівців, здатних до соціальної адаптації й забезпечення подальших якісних суспільних освітніх перетворень. Цей процес повинен відбуватись із дотриманням балансу традиційних та інноваційних технологій підготовки.

Прогресивним напрямом професійної підготовки майбутніх логопедів, на думку С. Цимбал-Слатвінської, $є$ забезпечення сприятливого інноваційного середовища для освітньої діяльності майбутніх фахівців, у якому інтегровано традиційні методи й новітні інформаційні технології (Цимбал-Слатвінська, 2020, с. 14).

На сьогодні важливим і нагальним напрямом оптимізації освітнього процесу в Україні $€$ академічна мобільність студентів-логопедів, яку необхідно розглядати як право на отримання ними якісної підготовки, набуття нового актуального досвіту, розширення кругозору та подальшу професійну самореалізацію. 
Академічна мобільність майбутніх учителів-логопедів повинна реалізуватися шляхом їх навчання, проходження навчальної і виробничої практик, проведення наукових досліджень у закладах-партнерах України (внутрішня академічна мобільність) та закордонних 3ВО-партнерах (зовнішня академічна мобільність). Це дасть можливість майбутнім учителямлогопедам набути нових професійних навичок, краще зрозуміти специфіку професійної діяльності, орієнтуватись у новітніх досягненнях спеціальної освіти, зокрема логопедії, бути залученими до кращих світових практик.

На основі вимог, які висуває сьогодні суспільство до професійної підготовки вчителя-логопеда як результату його навчання в закладі вищої освіти стає зрозумілим, що сучасний фахівець повинен мати не лише високий рівень компетентності, а й володіти високим рівнем розвитку професійно необхідних особистісних якостей, серед яких професійна та громадянська відповідальність відіграють провідну роль (Мартинчук, 2017, с. 157-158). До базових моральних якостей учителів-логопедів необхідно віднести: позитивне емоційне ставлення до дітей і професії; здатність до співпереживання, співчуття до проблем дитини та їі сім'ї; відповідальність за результати своєї діяльності та їх роль у подальшій долі дитини тощо.

Цілком зрозуміло, що особистісні якості майбутнього вчителя-логопеда визначаються специфікою його професійної діяльності, що передбачає не лише навчально-виховну, діагностично-консультативну, профілактичну та корекційно-розвивальну роботу з дітьми з порушенням мовлення, але й (у першу чергу) прийняття дитини з порушенням, можливість і необхідність надання допомоги у становленні ії як особистості. Тож, перед сучасними закладами вищої освіти постають завдання створення ефективних умов для професійного й особистісного саморозвитку майбутнього успішного фахівцялогопеда, розкриття та розвитку загальнолюдських та професійно значущих особистісних якостей (Мартинчук, 2017, с. 157-158).

Висновки та перспективи подальших розвідок. Таким чином, проведені розвідки дають можливість констатувати, що проблема професійної підготовки майбутніх учителів-логопедів потребує постійної уваги та оптимізації відповідно до актуальних вимог розвитку суспільства, наукового й технічного прогресу i виступає необхідною умовою ефективного здійснення ними специфічної професійної діяльності.

У ході дослідження визначено, що професійну підготовку майбутніх учителів-логопедів необхідно розглядати як складний, динамічний, багатокомпонентний та багаторівневий процес, який повинен забезпечувати формування професійної компетентності та особистісних 
якостей майбутнього вчителя-логопеда для ефективного здійснення ним фахової діяльності.

Прогресивними напрямами оптимізації освітнього процесу визначені: розроблення нових освітніх стратегій з урахуванням сучасних світових тенденцій підготовки фахівців у галузі спеціальної освіти, зокрема логопедії; використання актуальних досягнень у галузі педагогіки, психології медицини та інших суміжних галузях науки; урахування вітчизняних традицій, сучасних особливостей системи освіти дітей із порушенням психофізичного розвитку та новітніх розробок провідних країн світу; оновлення змісту, форм та методів підготовки, їх приведення у відповідність до вимог та потреб сучасності; створення ефективних умов для професійного й особистісного саморозвитку майбутнього успішного фахівця.

у подальшому більш ретельну увагу плануємо приділити розробленню теоретичних та методичних засад оптимізації професійної підготовки майбутніх учителів-логопедів у закладах вищої освіти України.

\section{ЛІТЕРАТУРА}

Гринькевич, О. С., Садова, У. Я., Левицька, О. О. (2019). Міжнародний досвід моніторингу працевлаштування випускників та шляхи його застосування в україні. Демографрія та соціальна економіка, 1 (35), 126-138. Режим доступу: https://dse.org.ua (Hrynkevych, O. S., Sadova, U. Ya., Levytska, O. O. (2019). International experience in monitoring graduates' employment and ways of its application in ukraine. Demography and Social Economy, 1 (35), 126-138. Retrieved from: https://dse.org.ua).

Дегтяренко, Т. М. (2015). Модифікація професійної підготовки фахівців у контексті модернізації системи спеціальної освіти. Педагогічні науки: теорія, історія, інноваційні технології, 3 (47), 3-10 (Dehtiarenko, T. M. (2015). Modification of professional training in the context of modernization of the special education system. Pedagogical sciences: theory, history, innovative technologies, 3 (47), 3-10).

Мартинчук, О. В. (2017). Компетентнісний підхід до фахової підготовки вчителівдефектологів для забезпечення освітньої інтеграції дітей з порушеннями психофізичного розвитку. Науковий часопис Начіонального педагогічного університету імені М.П. Драгоманова (корекційна педагогіка та спеціальна психологія), 24, 153-158 (Martynchuk, O. V. (2017). Competence approach to the professional training of special education teachers to ensure the educational integration of children with mental and physical disabilities. M.P. Dragomanov NPU Scientific Journal (Correction Pedagogy and Special Psychology, 24, 153-158).

Мороз, Л. В., Крот, Г. В. (2020). Професійна компетентність майбутнього магістралогопеда. Особистісно-професійна компетентність педагога: теорія $i$ практика: збірник матеріалів IV Всеукраїнської науково-методичної практичної конференції (27 лютого 2020 р.). Суми: НІКО, (сс. 206-208) (M oroz, L.V., Krot, H. V. (2020). Professional competence of the future master speech therapist. Personal-professional competence of a teacher: theory and practice: collection of materials of the IV All-Ukrainian scientific-methodical practical conference (February 27, 2020), (pp. 206-208)).

Пахомова, Н. Г. (2011). Системність як методологічна основа професійної підготовки вчителя-логопеда. Науковий часопис Національного педагогічного університету 
імені М. П. Драгоманова (корекційна педагогіка та спеціальна психологія), 18, 192196 (Pakhomova, N. H. (2011). Systematicity as a methodological basis for the professional training of a speech therapist. M. P. Dragomanov NPU Scientific Journal (Correction Pedagogy and Special Psychology, 18, 192-196).

Пахомова, Н. Г. (2013). Інтеграція медико-психологічної і педагогічної складових професійної підготовки в умовах кредитно-модульної системи. Педагогіка та психологія, 43, 63-72. Режим доступу: http://nbuv.gov.ua/UJRN/znpkhnpu_ped_2013 4312 (Pakhomova, N. H. (2013). Integration of medical-psychological and pedagogical components of professional training in the conditions of credit-module system. Pedagogy and Psychology, 43, 6372. Retrieved from: http://nbuv.gov.ua/UJRN/znpkhnpu ped 201343 12).

Пахомова, Н. Г. (2017). Діагностико-корекційний консалтинг в системі підготовки фахівця до роботи в умовах інклюзії. Матеріали Всеукраїнської (заочної) науково-практичної конференції. Спеціальна освіта стан та перспективи, (сс. 374-377) (Pakhomova, N. H. (2017). Diagnostic and correctional consulting in the system of preparation of the specialist for work in the conditions of inclusion. Proceedings of the All-Ukrainian (correspondence) scientific-practical conference. Special education status and prospects, (pp. 374-377)).

Сінопальникова, Н. М. (2014). Підготовка майбутніх вчителів-логопедів до професійної діяльності. Засоби навчальної та науково-дослідної роботи, 43, 173-182 (Sinopalnikova, N. M. (2014). Training of future teachers-speech therapists for professional activity. M eans of educational and research work, 43, 173-182).

Синьов, В. М., Шеремет, М. К. (2015). Основні тенденції модернізації підготовки корекційних педагогів в умовах реформування освітньої галузі. Педагогічні науки: теорія, історія, інноваційні технології, 7 (51), 390-396 (Syniov, V. M., Sheremet, M. K. (2015). The main trends in the modernization of the training of correctional teachers in terms of reforming the education sector. Pedagogical sciences: theory, history, innovative technologies, 7 (51), 390-396).

Цимбал-Слатвінська, С. В. (2020). Теорія і практика професійної підготовки майбутніх логопедів в умовах інформаційно-освітнього середовища вищих навчальних закладів (автореф. дис. ... д-ра пед. наук: 13.00.04). Умань (Tsymbal-Slatvinska, S. V. (2020). Theory and practice of professional training of future speech therapists in the information and educational environment of higher educational institutions (DSc thesis abstract). Uman).

Шеремет, М. К., Супрун, Д. М., Кондукова, С. В. (2020). Професійна підготовка фахівців спеціальної освіти в умовах сьогодення. Матеріали IV Всеукраїнської науковопрактичної конфреренції. Інноваційні підходи в освіті та реабілітації дітей із особливими освітніми потребами, (сс. 6-10). Режим доступу: https://fsio.npu.edu.ua/images/ (Sheremet, M. K., Suprun, D. M., Kondukova, S. V. (2020). Professional training of special education specialists in today's conditions. Proceedings of the IV All-Ukrainian scientific-practical conference. Innovative approaches in education and rehabilitation of children with special educational needs, (pp. 6-100. Retrieved from: https://fsio.npu.edu.ua/images/).

\section{PEЗЮME}

Мороз Людмила, Стахова Лариса, Кравченко Анатолий, Кравченко Ирина, Зелинская-Любченко Екатерина. Современные проблемы профессиональной підготовки будущих учителей-логопедов.

В статье конкретизированы основные проблемы профессиональной подготовки будущих учителей-логопедов в высших образовательных учреждениях на современном 
этапе развития общества. Авторы отмечают, что профессиональную подготовку будущих учителей-логопедов необходимо рассматривать как сложный, динамичный, многокомпонентный и многоуровневый процесс, который должен осуществляться с учетом современных мировых тенденций подготовки специалистов в области специального образования. Прогрессивными направлениями оптимизации образовательного прочесса авторами определены: использование актуальных научных достижений; учет отечественных традиций и новейших разработок ведущих стран мира; обновление дидактического обеспечения и создание эфрфективных условий для профессионального и личностного саморазвития будущего успешного специалиста-логопеда.

Ключевые слова: профрессиональная поготовка, профессиональная компетентность, будущий учитель-логопед, студенты-логопеды, учреждение высшего образования.

\section{SUM MARY}

Moroz Liudmyla, Stakhova Larysa, Kravchenko Anatolii, Kravchenko Iryna, ZelinskaLiubchenko Kateryna. Modern problems and prospects of professional training of future teachers-speech therapists.

The article identifies the main problems and prospects for professional training of future teachers-speech therapists at higher education institutions at the present stage of society development.

Research methods: analysis, systematization and generalization of data of scientific and methodological, special literature and electronic resources; analysis of speeches of leading scientists in the special education field, current issues discussion and challenges at scientific and practical events of different levels and comparison of different views on the research problem.

It is determined in the article that the existing system of professional training of future teachers-speech therapists in modern conditions justifies itself only partially. Currently, there is a need to train a new generation of teachers-speech therapists - qualified professionals, who do not only have the necessary knowledge, skills and abilities, but also are capable of personal development, creative self-realization, continuous professional self-improvement, open to interaction, professionals with active professional position effectively carry out specific professional activities in modern conditions. Such guidelines will increase the education institutions competitiveness and train specialists at the appropriate level, in line with international standards, able to meet not only the needs of the domestic labor market, but also to compete with graduates of leading European higher educational institutions.

The authors emphasize that professional training of future teachers-speech therapists should be considered as a complex, dynamic, multicomponent and multilevel process, which should take into account current global trends in the training of specialists in the special education field. Progressive areas of educational process optimization, the authors have identified: the use of current scientific advances; taking into account domestic traditions and the latest developments of the world's leading countries; updating the didactic support and creating effective conditions for professional and personal self-development of the future successful speech therapist.

Key words professional training, professional competence, future teacher-speech therapist, students-speech therapists, institution of higher education. 